Canadian Studies in Population, Vol. 32.1, 2005, pp. 97-130

\title{
Social Structures and the Occupational Composition of Skilled Worker Immigrants to Canada
}

\author{
Heather Dryburgh \\ Social and Aboriginal Statistics Division \\ Statistics Canada \\ Ottawa, Ontario, Canada
}

\begin{abstract}
The individual decision to immigrate is made in the context of larger social structures that influence the composition of the economic immigrant population over time. Over the last 20 years, economic immigrants to Canada have faced changing selection policies, cycles of economic recession and growth, increased demand for information technology skills, women's increased labour force participation and an aging labour force. Using data from Statistics Canada's Longitudinal Immigration Database (IMDB), this paper examines the flow of economic immigrants to Canada by their occupational composition from 1980 to 2000. Relative to Canadians, when all immigrants from this period are grouped together, their economic integration is slow and does not reach parity with Canadians before 16 years. Among skilled worker immigrants, whereas the earlier cohorts did well but did not improve much over time, later cohorts started off in a relatively worse position, but early indications show a fairly steep slope to better relative average earnings. These differences support the need to examine immigrant integration by both the class of immigrant and the context at the time of immigration.
\end{abstract}

Key Words: Skilled worker immigrants, occupational composition, Longitudinal Immigration Data Base, immigrant integration 
Heather Dryburgh

\section{Résumé}

La décision d'immigrer est une décision personnelle prise dans le plus large contexte des structures sociales qui, à leur tour, exercent une influence sur la composition de la population immigrante selon les époques. Pendant les vingt années dernières, les immigrants économiques au Canada ont dû faire face à des changements de polices de sélection, à des cycles de récession et de croissance économique, à une demande accrue des techniques d'informatiques, à la participation accrue des femmes dans la population active et à une population active plus âgée. En s'appuyant sur les données de la Banque de données longitudinales sur les immigrants (BDIM), cet article examine le flux d'immigrants économiques au Canada entre 1980 et 2000, selon la composition de leurs métiers. En comparaison avec les Canadiens, quand tous les immigrants de cette période sont examinés en bloc, leur intégration économique est assez lente et prendra au moins 16 ans à atteindre un niveau de parité avec les Canadiens. Parmi les immigrants qui sont ouvriers qualifiés, il est démontré que bien que les premières cohortes trouvaient un certain succès assez rapidement, leur situation ne s'améliorait pas avec le temps alors que si les cohortes plus récentes semblent avoir commencé dans de pires situations, certaines indications démontrent une montée plus rapide vers de meilleurs gains moyens relatifs. Ces différences prouvent le besoin d'examiner l'intégration des immigrants selon la classe d'immigrants ainsi que par le contexte de la période de leur immigration.

Mots-clés : Les immigrants ouvriers qualifiés, la composition occupationnelle, la Banque de données longitudinales sur les immigrants, l'intégration immigrante.

\section{Introduction}

Recent evidence has brought to light a downward income trend for new immigrants to Canada (Chui \& Zietsma 2003, Green \& Worswick 2002, Ruddick 2004) that shows immigrants landing (i.e.: gaining permanent residency) in 1980 integrated more quickly and were doing better ten years after immigration than those landing in Canada in 1990. Figure 1 shows the average employment earnings for up to 16 years for all immigrants by cohort. Standardized to be comparable to the Canadian population age structure, and 
indexed to the average earnings for all Canadians, the trend shows clearly that 1990s immigrants are starting out with lower incomes and after 11 years, the 1990 cohort has still not reached that of the 1981 cohort. Various explanations for this have been explored, including such structural factors as the effect of the business cycle on immigrant labour market experiences (Aydemir 2003), the shift to a knowledge-based economy (Reitz 2000, Boyd \& Vickers 2000), and the shifting categories mix of immigrants (Ruddick 2004). While these kinds of structural factors are now known to be associated with the economic integration of immigrants, they may also have an additional indirect effect on the same phenomenon by influencing the occupational composition of immigrants, and thus their comparative economic success, over time.

From 1980 to 2000, immigrants to Canada have faced changing selection policies, cycles of economic recession and growth, changes in labour supply and demand for various occupational groups, women's increased labour force participation and an aging labour force. Occupational supply and demand can influence the kinds of immigrants that decide to come to Canada, and may contribute to their integration. Taking advantage of landing cohort and immigrant category information, the first objective of this paper is to identify significant changes in the occupational composition and characteristics of skilled worker immigrants over time, and to set these within the context of the social structures that varied during that period. We then look more closely at one specific occupational group - Information technology workers - to examine this dynamic more closely.

\section{Literature Review}

Previous research has examined the structural forces constraining and enabling the choices of individuals primarily in relation to two related questions: 1) Who immigrates? and 2) Why are immigrants not doing as well economically as previously, or as the Canadian-born population? Concerning migration decisions one approach has been to look at the impact of changing selection criteria on the composition of entire immigrant cohorts (Boyd \& Vickers, 2000; Aydemir, 2002; Green \& Worswick, 2002). For example, Aydemir (2002) found that the change in immigration policy had the effect of raising the average education level of immigrant skilled workers. Boyd \& Vickers (2000) found that the implementation of the 1976 Immigration Act that based selection more on individual characteristics rather than country of origin regulations meant that the 1980s and 1990s were characterized by greater cultural diversity and a growing visible minority population in Canada (Boyd \& Vickers, 2000). A well-known issue for women and men immigrants is the initial impact and earnings lag associated with getting recognition for their credentials and work 
Figure 1: All immigrants indexed and age-standardized average earnings, landing cohorts by years since landing

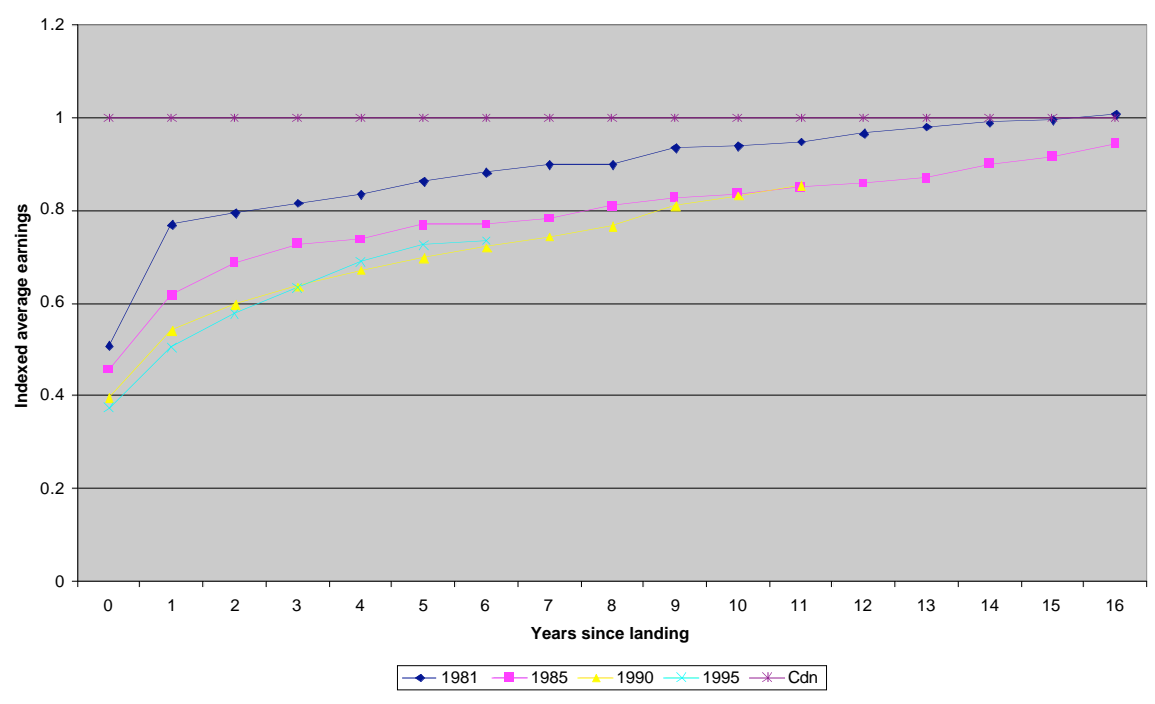

Source: Longitudinal Immigration Data Base, Statistics Canada

experience, particularly if they are from parts of the world where the educational institutions are not very well known to Canadian employers or professional associations (Boyd \& Thomas 2001, Green \& Worswick 2002; Najm 2001). Likewise, Najm (2001) found that immigrants from Asia, Africa and SouthAmerica were penalized when it came to recognition of foreign credentials (p. 22), and professionals from these source areas were often penalized whether their credentials were foreign or locally obtained.

These studies contribute significantly to our understanding of the relationship between the Immigration Act and the resulting composition of immigrant cohorts generally, nevertheless they also draw attention to the complexity of the second question of why recent immigrants are not doing as well as previous cohorts. It is not clear the extent to which being a visible minority disadvantages new immigrants at the same time as they arrive with higher qualifications than ever before.

Another approach to understanding migration decisions from a structural perspective looks more closely at the impact of the relationship between sending and receiving countries, particularly at trade relations, outsourcing of work, and 
other agreements that may facilitate the flow of immigrants from one country to the other (Sassen 1988, Kim 2003). While Canadian studies of this nature are limited, Kim (2003) examines the impact of trade activity and foreign investments on Canadian immigration and finds little effect. One shortcoming of this research, as Kim notes, is the inclusion of all immigrant classes in the analysis, whereas the impact of these structures may be more relevant for economic migrants than family reunifications or refugees.

The second question focuses on structural impacts on the economic integration of immigrants. A good example of this kind of research is a study by Green \& Worswick (2002) who considered changes in Canadian immigration policy in their analysis of labour market entry effects and the earnings returns to immigrant men for their foreign experience. They found that changes in the source country composition of immigrant cohorts from the 1980s to early 1990s, as well as a decline in returns to foreign experience through this period explained declines in entry earnings across immigrant cohorts that could not be explained by general declines experienced by all new entrants to the Canadian labour market. For economic immigrants specifically the effect of source country composition and declining returns to foreign experience was greater for older immigrants than younger immigrants regardless of cohort.

Using a similar approach, Aydemir (2003) developed a model to examine the impact of the business cycle on labour force participation by new immigrants. $\mathrm{He}$ found that labour force participation was affected by entry conditions attributed to the business cycle, with adverse effects at times when unemployment rates were high. Since labour supply and demand vary by occupation as well as by other factors such as geographic location, this general finding of the impact of unemployment rates on immigrants' labour force participation should be seen as a starting point for a more detailed analysis taking into account specific occupations.

In another significant contribution to the question of structural effects on immigrant employment and income, Reitz (2000) studied what he called "institutional effects"- immigration policy, social welfare systems and educational institutions - for their effect on immigrant employment trends and earnings. He concluded that employment trends for immigrants may be linked to some aspects of their country of origin. He argued that the Canadian-born are catching up to immigrant high education levels as these credentials are becoming increasingly required in the labour market of the emerging knowledge-based economy. The combination of these trends means a decline in relative earnings for new immigrants. 
Heather Dryburgh

Much of the data used for the immigrant research summarized above does not provide key information such as immigrant class (e.g. refugee, skilled worker, family class), nor has it been easy to find detailed occupation data together with economic and immigrant information. As a result, studies on immigrant economic integration often group skilled workers together with family class immigrants and refugees. Anecdotal evidence suggests that there are important differences between the experiences of these groups of immigrants. This paper uses data from the Longitudinal Immigration Database, which identifies immigrant classes and has detailed occupation and earnings information. The analysis adds to the previous research by focusing either specifically on skilled worker economic immigrants (principal applicants) who must meet certain selection criteria to gain permanent residency in Canada, or on all economic immigrants which includes skilled workers and other independent immigrants such as investors or entrepreneurs. Although skilled workers or other economic class immigrants may migrate for reasons associated with problems in the sending country, they are admitted to Canada based on their resources and characteristics. Therefore the relationship between structural forces in Canada and the occupational composition of these immigrants should be clearer than for family reunifications or refugees.

The aim of the paper is to bring together background contextual information on the economic and social situation into which immigrant cohorts landed in the 1980s and 1990s in Canada and examine the relationship of that context to the occupational composition of these cohorts of immigrants. To explore in more detail the relationship between the social structures and the economic integration of immigrants, the paper then focuses on the example of immigrants intending to work in occupations in Information Technology (IT). This section considers the ease with which immigrant IT workers are moving into the labour force and the stability of their employment in Canada over time, given the context of their period of immigration.

\section{Methods}

\section{Data}

Although this paper draws on data from a variety of Statistics Canada sources, most of the analysis is based on data from Citizenship and Immigration's landings file (LIDS) and Statistics Canada's Longitudinal Immigration Database (IMDB). The landings file includes information on immigrant characteristics at the time of gaining permanent residency in Canada, including detailed information on their intended occupation. Immigrants are asked to report their 
intended occupation on entering Canada and to provide evidence of credentials and length of experience working in that occupation ${ }^{1}$.

The IMDB combines administrative immigration and taxation records into a comprehensive source of data on the labour market behaviour of the landed immigrant population ${ }^{2}$ in Canada. The data are managed by Statistics Canada on behalf of a federal-provincial consortium led by Citizenship \& Immigration Canada (CIC). The database currently covers the period 1980 to 2001 with up to 16 years of information on immigrant tax-filers. The IMDB is the only source of Canadian longitudinal data with a sufficient sample of immigrants to examine immigrant settlement and integration patterns over time and by characteristics at arrival and selection criteria.

\section{Immigration Periods}

Given the character of the twenty year period of interest, this study divides immigrant landing cohorts into four periods: 1981 to $1985 ; 1986$ to $1990 ; 1991$ to 1993; and 1994 to 2000. The following discussion shows how each of these periods varies in some key ways from the others. The structural forces described in detail below set the context for the discussion of the occupational composition of skilled worker immigrants landing in each period which follows.

\section{The Canadian context from 1980 to 2000}

The United Nations (UN) Migration Report, 2002 identifies a recent global trend toward more policy restrictions on migration, with greater selectiveness in admission criteria and a tendency to favour immigrants bringing capital to invest or specific skills to meet labour needs. Although this captures some aspects of Canadian immigration, Canada has in fact embraced a more expansionist immigration policy than many other industrialized countries (Reitz 2000, UN 2002). The number of landed immigrants to Canada landing in a given year went from 143,135 in 1980 to 227,313 in 2000 (Facts and Figures, 2001), with skilled workers also showing an overall increase through this period (Figure 2). The share of skilled worker principal applicants fluctuated over this period, with low periods through the mid-1980s and the early 1990s, and peaks in the late 1980s and late 1990s (Figure 3). 
Heather Dryburgh

\section{Immigrant Selection Criteria}

Since 1967, Canada's immigration policy has been based on non-discriminatory principles of selection. Applicants have been accepted based on universal criteria related to their ability to successfully integrate into Canadian life. The 1976 Immigration Act (the Act) came into effect in 1978 and remained in place until 2002 when the Immigration and Refugee Protection Act came into effect. The Act had been amended more than 30 times (CIC, 2002) in its 26 years. Nevertheless, the key tenets of this act held throughout its lifetime - to reunite families, to protect refugees deemed to be in genuine need of protection, and to promote Canada's economic development. Only those aspects and changes to the Act that are relevant to skilled workers will be discussed here.

The Act provided for the recruitment of skilled immigrants based on government-established levels of immigration and on the units of assessment (referred to hereafter as points) selection system. Applicants under the skilled worker class are required to pass specified levels of points to be approved for permanent residency in Canada (see Appendix 1). The selection system is flexible, allowing for adjustment to reflect changing needs, and planned levels of immigration in relation to demand in the other main immigrant groups family reunification and refugee protection (McWhinney 1998).

Key modifications to the Act included a temporary restriction on skilled workers from May 1982 to January 1986 that required skilled worker immigrants to have a validated job offer before their application would be accepted for consideration. The selection criteria were revised in January 1986 to increase the number of skilled workers and these revisions included removing the temporary restriction put in place in 1982. In addition, the revisions of 1986 included some shifts in the allocation of points for certain criteria.

The other significant change introduced in 1986 of relevance to this study was the shift away from the use of the Occupational and Area Demand report ${ }^{3}$ as a means of controlling the occupational composition and the immigration levels of skilled workers. Instead, demographic demand was set with a levels control factor of up to 10 points, and occupational composition was controlled by points allocated based on occupational demand. Occupational demand points were set according to the employment opportunities available in Canada for the occupation in which the immigrant intended to work and for which the immigrant was qualified ${ }^{4}$. Those skilled workers whose occupations were not assigned at least one point would not be considered for permanent residency. Also at this period, immigrants who had arranged employment waiting for them continued to be allocated 10 points and there was no penalty for not having arranged employment as had earlier been the case: however, being in a 
Social Structures and the Occupational Composition of Skilled Worker Immigrants to Canada
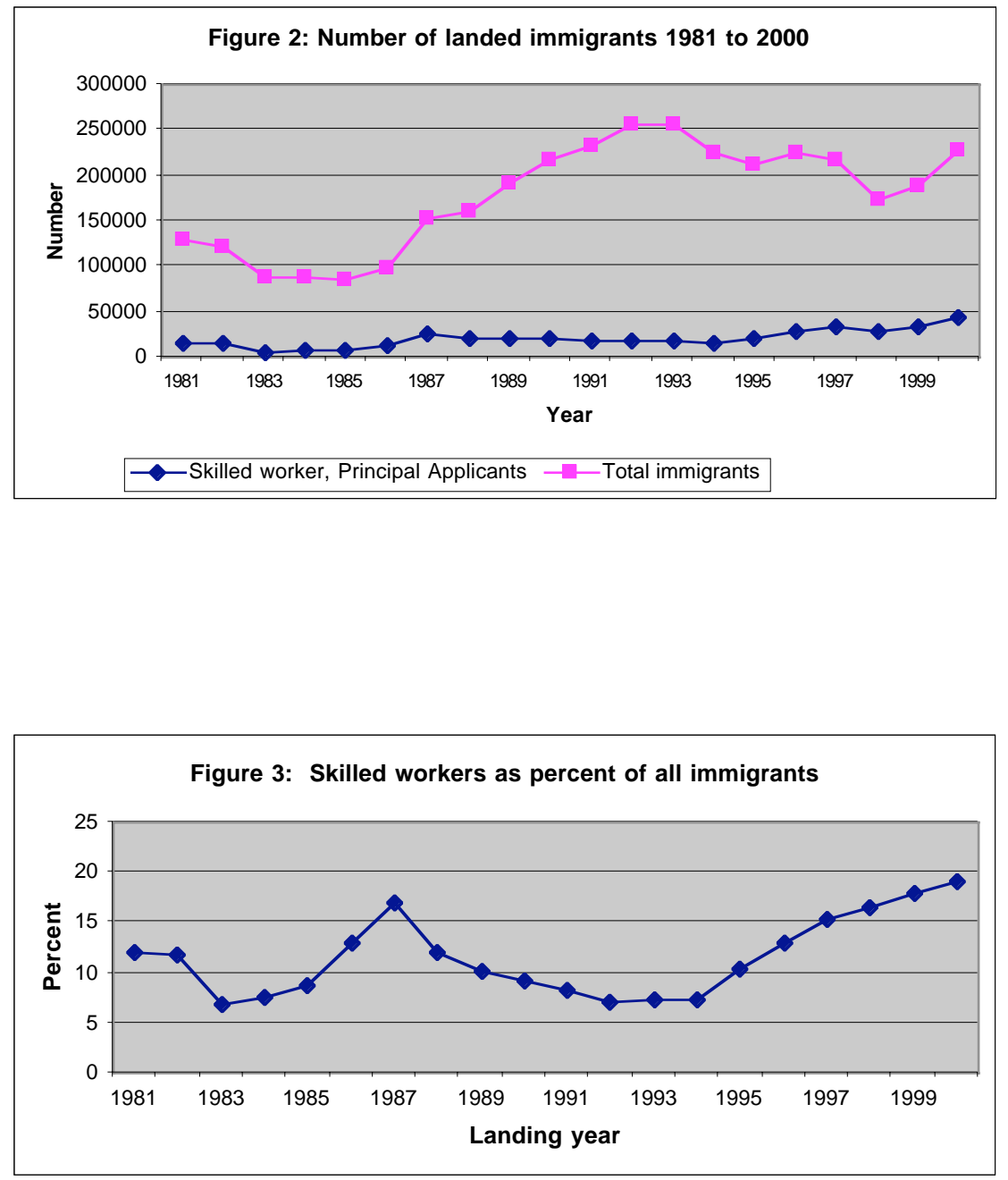

Source Figures 2 and 3: LIDS, Citizenship and Immigration Canada 
Heather Dryburgh

designated occupation (an occupation designated as having a shortage of workers) was no longer considered equivalent to having arranged employment.

Other key changes occurring in 1986 were the increase in the pass mark from 50 points to 70 points and a shift in the age factor from 18-35 years receiving top points, to 21-44 years. There was a reduction of 2 points for each year over age 44 or under age 21 . Knowledge of official languages received five more points than was the case prior to 1986 , whereas a possible 5 points for settling in a location where there was a need for immigrants was eliminated.

The 1986 revisions were aimed at addressing the declining numbers of economic immigrants in the mid-1980s and restoring a better balance between economic, family and humanitarian immigrants. They were intended to increase the number of independent applicants, including skilled workers, and to support Canada's economic development by recruiting immigrants who would meet the needs of Canada's labour market (McWhinney, 1998).

In 1991 the allocation of points for designated occupation was re-instituted, and in 1992 those immigrants with arranged employment or destined to designated occupations were given higher processing priority than before.

Another major revision to the Act in 1993 aimed to better reward immigrants in occupations that required higher skills and admit a greater number of these highly skilled immigrants to meet Canadian labour demands and positively impact the Canadian economy. Accordingly, the points for specific vocational preparation were increased from 15 to 18 , and applicants with post-secondary education now received more points than those with secondary education for the first time. Points for language ability were modified to reward bilingual applicants and reduce points previously given to those who could speak, write or read in an official language only with difficulty. Also in 1993, the Levels Control which had been introduced in 1986 and set at 5 points out of a possible 10 , was increased to 8 points to increase the number of economic immigrants admitted. The 1993 changes meant that Canada was looking to recruit more economic immigrants, and these were to be highly skilled, highly educated immigrants with ability in Canada's languages (McWhinney, 1998).

\section{The Business Cycle and Labour Supply and Demand}

The 1980s and 1990s were both decades characterized by periods of recession, recovery and growth. Although 1983 marked the beginning of economic recovery in the 1980s, immigration policy required economic immigrants to have a guaranteed job in Canada in order to be considered for selection at that 
time. The year 1986 saw the beginning of an economic boom that continued to the end of the decade. By the early 1990s the Canadian economy had suffered another downturn, however, unlike the recession of the early 1980s, the levels of skilled workers landing in the early 1990s remained consistent through this period, and overall immigration continued to increase. Reitz (2000) argues that this stability in immigration policy in the 1990s indicated recognition that the long-term benefits of high immigration levels outweigh short-term difficulties. The mid 1990s were characterized by another upturn in the economy and a notable increase in economic activity, particularly for the information and communication technology (ICT) sector (Vaillencourt, 2003; Bowlby \& Langlois, 2002).

Following the business cycle of economic strength, recession and recovery, the unemployment rate varied over the two decades of interest. The years 1982 to 1985 were characterized by relatively high unemployment rates, followed by declining unemployment rates to 1990. The largest numbers of Canadians in any occupational group were in sales and service occupations through the late 1980 s to 2003 and the numbers were steadily growing. Based on unemployment rates by occupation (Table 1), the demand for sales and service workers was fairly low throughout both decades relative to other occupations, but was particularly so in the early 1990s. Large numbers of Canadians also worked in trades and transport and clerical occupations, with employment levels for these occupations remaining fairly stable to the end of the 1990s. The unemployment rates for trades and transport workers reflected low demand that increased fairly sharply through the 1990s, however, high unemployment for these occupations may also be a reflection of the contractual or intermittent nature of this type of work. Likewise the demand for clerical workers is generally lower than other occupational groups, fell in the early 1990s and has been increasing through the mid to late 1990s.

The lowest unemployment rates, indicating high demand for these occupational groups, were in professional and technical health occupations, management occupations and professional occupations in business and finance. The unemployment rates for these occupational groups were less dramatically influenced by the downturn in the economy in the early 1990s, although most occupational groups benefited by the subsequent improved economy, characterized by declining unemployment rates through the mid to late 1990s, particularly for high skilled occupational groups (Green \& Worswick, 2002). For example, the demand for trades people and health care workers grew through the late 1990s, along with demand for IT workers, specifically computer scientists and programmers who had the skills required to work in research and development (Krebs \& Garneau, 2000, Bowlby \& Langlois, 2002). 
Heather Dryburgh

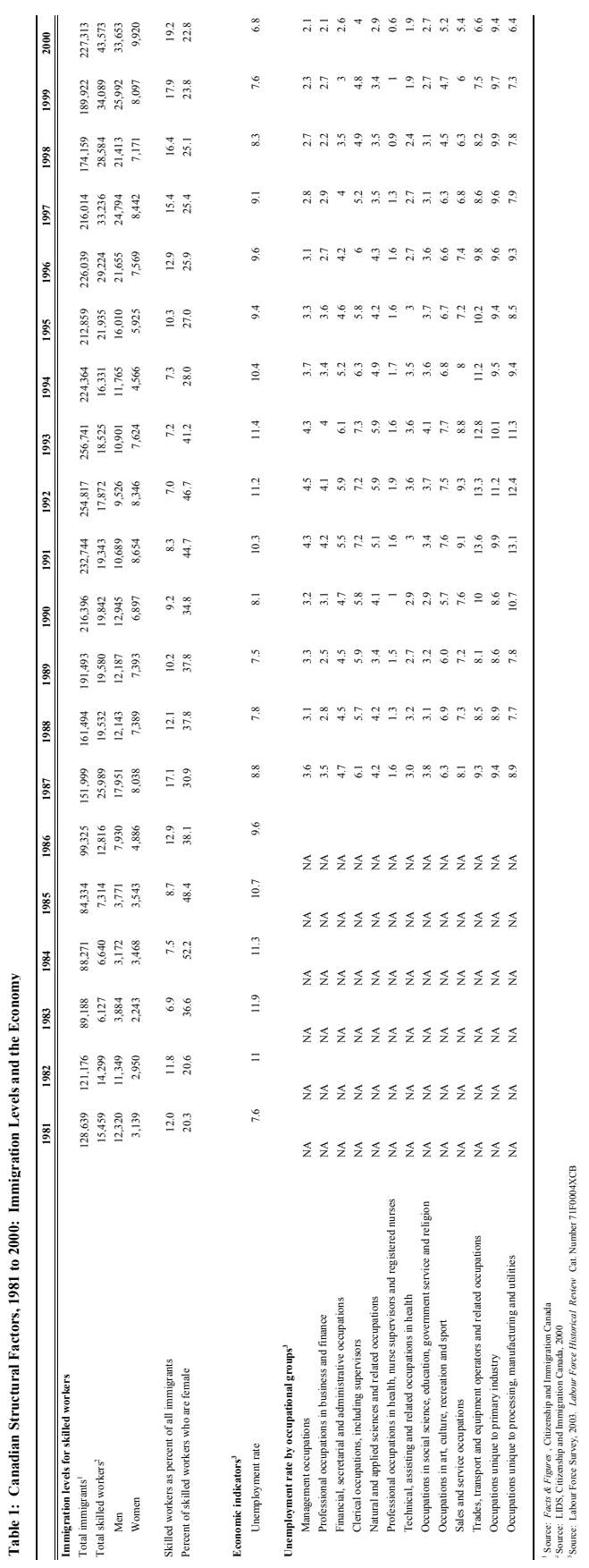


Social Structures and the Occupational Composition of Skilled Worker Immigrants to Canada

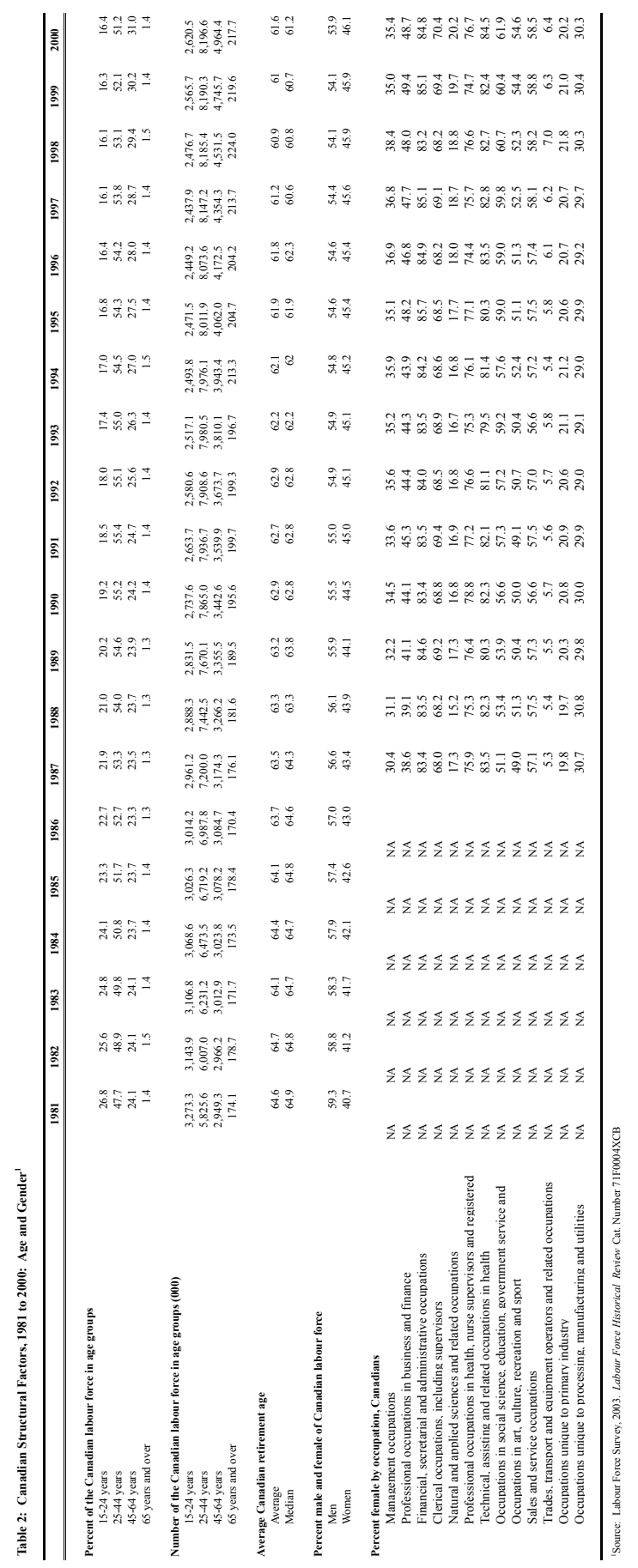


Heather Dryburgh

\section{Age Trends in the Canadian Labour Force}

The average age of all workers (immigrants and non-immigrants) in Canada has been getting older as the baby boomers age. In addition, the retirement ages of workers has been getting younger. These phenomena impact some industries and occupational groups more than others, with health and education industries feeling the greatest impact (MacKenzie \& Dryburgh, 2003). Older average ages and younger retirement ages suggest that these industries will be vulnerable to labour shortages as the baby boomers ${ }^{5}$ begin to retire. Among the broad occupational groups, MacKenzie \& Dryburgh (2003) find that Canadian managers and those working in health, education and utilities industries are older, on average, than other occupational groups, while sales, clerical and production workers on average are younger. The younger occupational groups may begin to be short of qualified young workers as fewer enter the labour force. In addition, the educational requirements for many occupations have increased over the last two decades and those occupational groups requiring higher education will have fewer workers in the younger age groups.

\section{Gender Trends in the Canadian Labour Market}

Women (immigrants and non-immigrants) now comprise a larger share of the Canadian labour force than was the case in the early 1980s (Table 1). Nevertheless, women's participation has been characterized by occupational segregation, with women dominating financial secretarial and administrative occupations, technical and professional occupations in health, and clerical occupations. Although women are a small minority in natural and applied science occupations, they have shown a proportional growth since 1987. Other occupational groups where women's proportional representation grew in this period are management, professional occupations in business and finance, and occupations in social science, education, government and religion. These occupational groups generally require high levels of education, and with the exception of the social science occupations are all male-dominated. The increasing numbers of women entering the labour force appear to be having an impact on the composition of typically male-dominated occupations, although women still comprise only a small proportion of these occupations. More Canadian competition for jobs in these occupational groups may mean immigrants with these occupational skills will be in less demand than others.

The overall proportion of women immigrants to Canada has increased in recent years mainly as a result of growing numbers of family reunification migrations (Boyd and Vickers, 2000), but women skilled worker migrants have also increased in the last two decades from 3,139 in 1981 to 9,920 in 2000. As a 


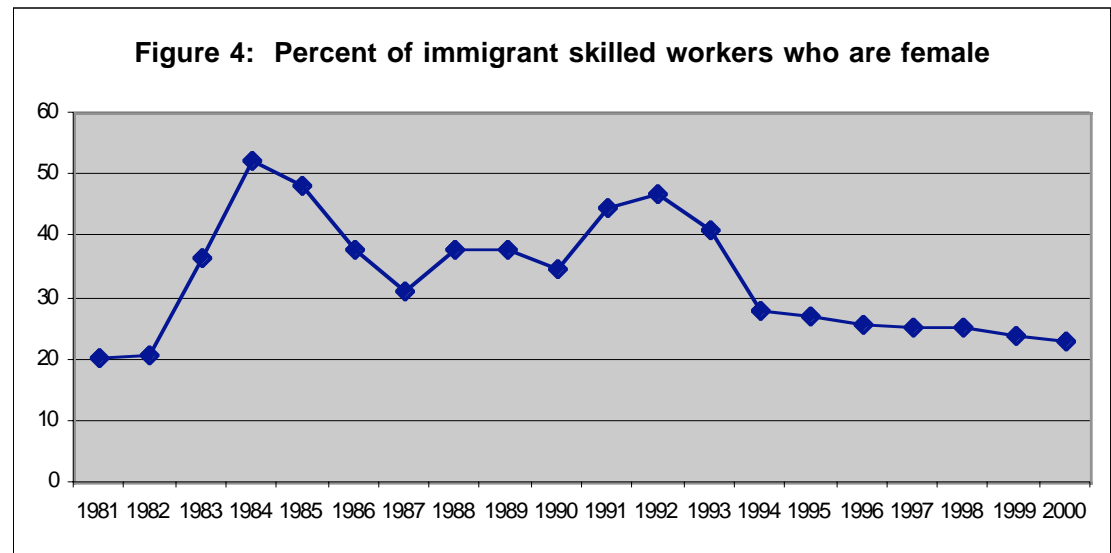

Source: LIDS, Citizenship and Immigration Canada

proportion of all skilled workers, however, women's percentages tend to reflect fluctuations in the numbers of men skilled workers (figure 10). The number of women skilled workers was smaller, but more stable throughout this period than the number of men.

\section{The Occupational Composition of Immigrants}

\section{1 to 1985}

To summarize, the 1981 to 86 immigration period was characterized in Canadian immigration policy by limited skilled worker admittance and a focus on arranged employment over general skills and education. This was a time of economic recession and the beginning of recovery, with an unemployment rate in 1983 at its highest level of the two decades. The aging_of the labour force was just beginning, but already there was evidence of a decline in the number of 15 to 24 year olds in the labour market. The rise in the percentage of women in the labour market was evident through this period. 
Heather Dryburgh

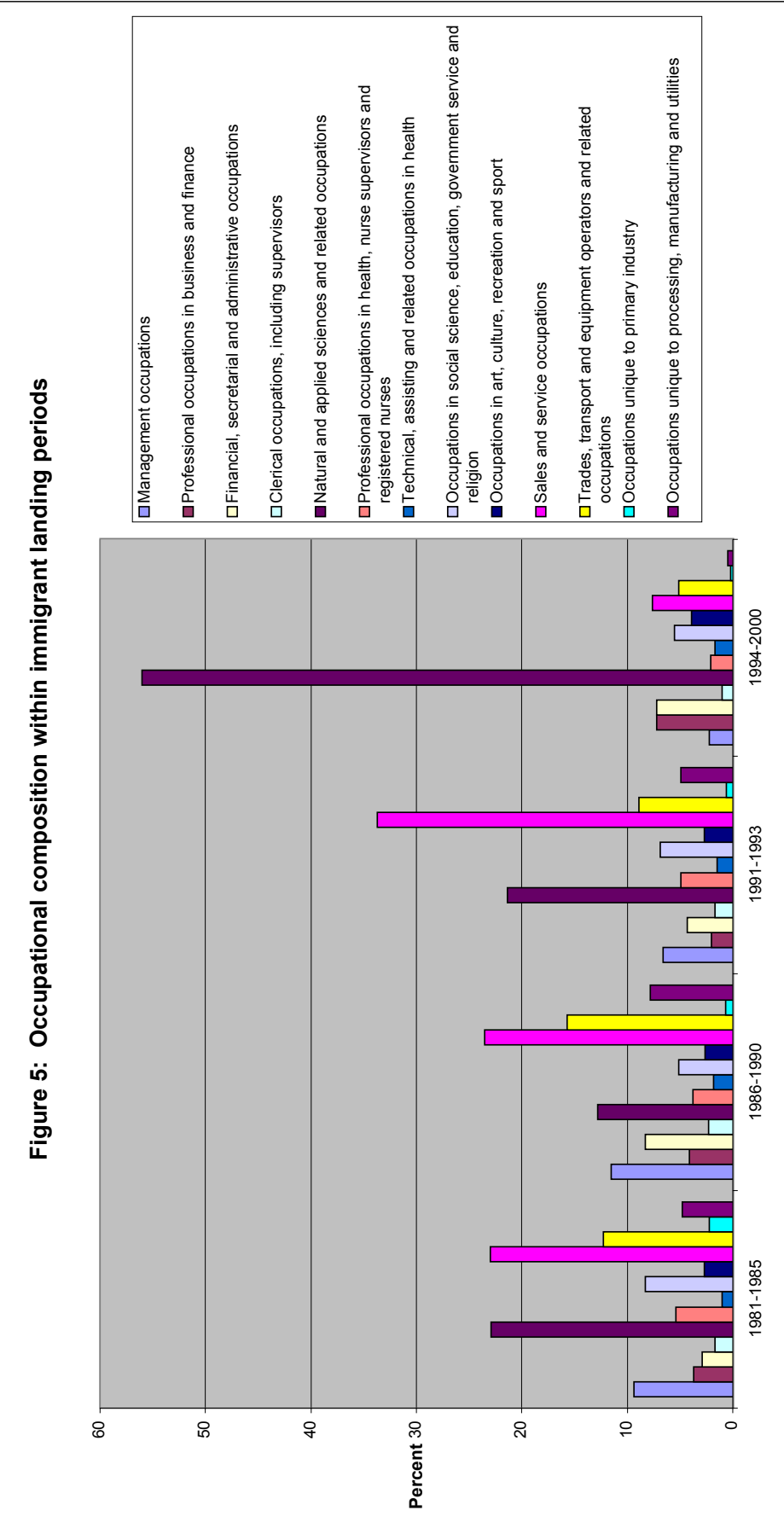


Approximately 49,780 skilled worker immigrants became permanent residents in Canada during this period ${ }^{6}$. Almost half of these skilled workers intended to work in natural and applied sciences occupations or sales and services occupations, with a further 22 percent intending to work in management or trades occupations. Although their numbers were fairly small, the proportion of immigrants in this period intending to work in professional occupations in health, or in social science, education, government or religion occupations was higher compared with other periods.

The age distribution of skilled worker immigrants varied over the four periods, with the youngest cohorts landing during the 1981 to 1985 period; approximately $40 \%$ of skilled worker immigrants to Canada during this period were in their twenties. This makes sense given the immigration points system that changed from 18-35 to 21-44 years in 1986.

A higher percentage of skilled worker immigrants landed with university degrees in the 81 to 85 cohorts than the 86 to 90 cohorts. In the 1980s the percentage with a trade certificate was fairly high, but declined significantly through the 1990s. That arranged employment was the key criterion for skilled immigrants rather than education or other selection criteria up to 1993 is evident by the fairly high percentage of skilled worker immigrants with less than 13 years of schooling in the pre-1994 cohort groups.

In the 81 to 85 period close to half of skilled worker immigrants came from Europe, with a fairly large proportion of the remaining immigrants coming from Asia and North America. Figure 9 shows the average indexed and agestandardized earnings of skilled worker immigrants to Canada in this period. Clearly skilled workers landing in 1981 to 85 did well compared to the Canadian average, however over their first 16 years there was not much growth in average earnings for this group relative to Canadians. The strong performance of this cohort may be related to having arranged employment, the good economic conditions, and the fairly high proportions intending work in the natural sciences. In addition, these workers were younger than the baby boomers and the large increase of women entering the labour market was just in the early stages.

\section{6 to 1990}

The second period, 1986 to 1990 was characterized by an immigration policy more favourable to skilled workers, but still prioritizing refugees and family reunification. It was no longer necessary to have arranged employment, but the selection process required more points to pass, and the preferred ages increased 
Heather Dryburgh

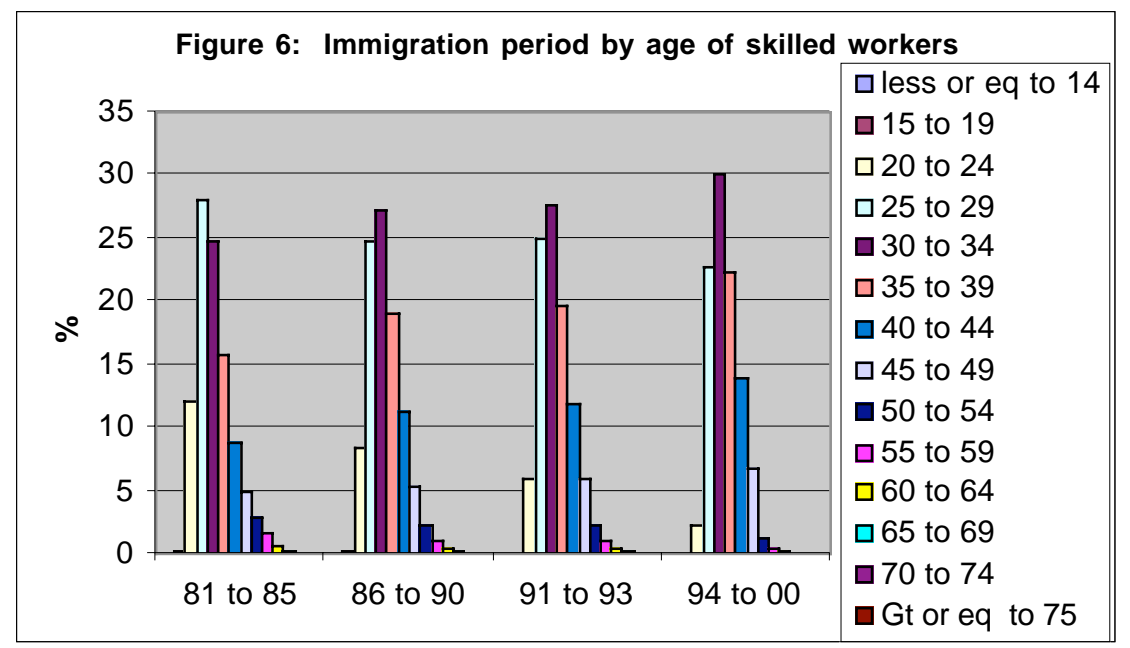

Source: LIDS, Citizenship and Immigration Canada

to 21-44 years. The economic boom was improving the labour market situation as evidenced by a decline in the unemployment rates for most occupational groups. The lowest unemployment rates were for the occupational groups requiring high education, such as health, management and occupations in the social sciences, education, government and religion group, suggesting possible shortages of workers in these occupational groups. Unemployment rates were higher, but declining for sales and services and trades occupations up to 1989, providing a potential window of opportunity for younger workers and other immigrants who intended working in these occupations. Women immigrant skilled workers landing in this period did so at a time when Canadian women's increasing numbers were perhaps at their steepest increase of the two decades of interest.

The number of skilled worker immigrants who became permanent residents in Canada between 1986 and 1990 increased substantially from the previous period to approximately 97,700. Although the demand in this period was high in the health, management and social science occupational groups, the largest occupational groups of immigrants were intending work in sales and service and trades occupations, which accounted for about $40 \%$ of skilled worker immigrants. The combination of the lower demand for sales and service workers, and the fact that these jobs were in the lower income range on average may help explain why immigrants of this cohort group did not do as well as the 
Social Structures and the Occupational Composition of Skilled Worker Immigrants to Canada

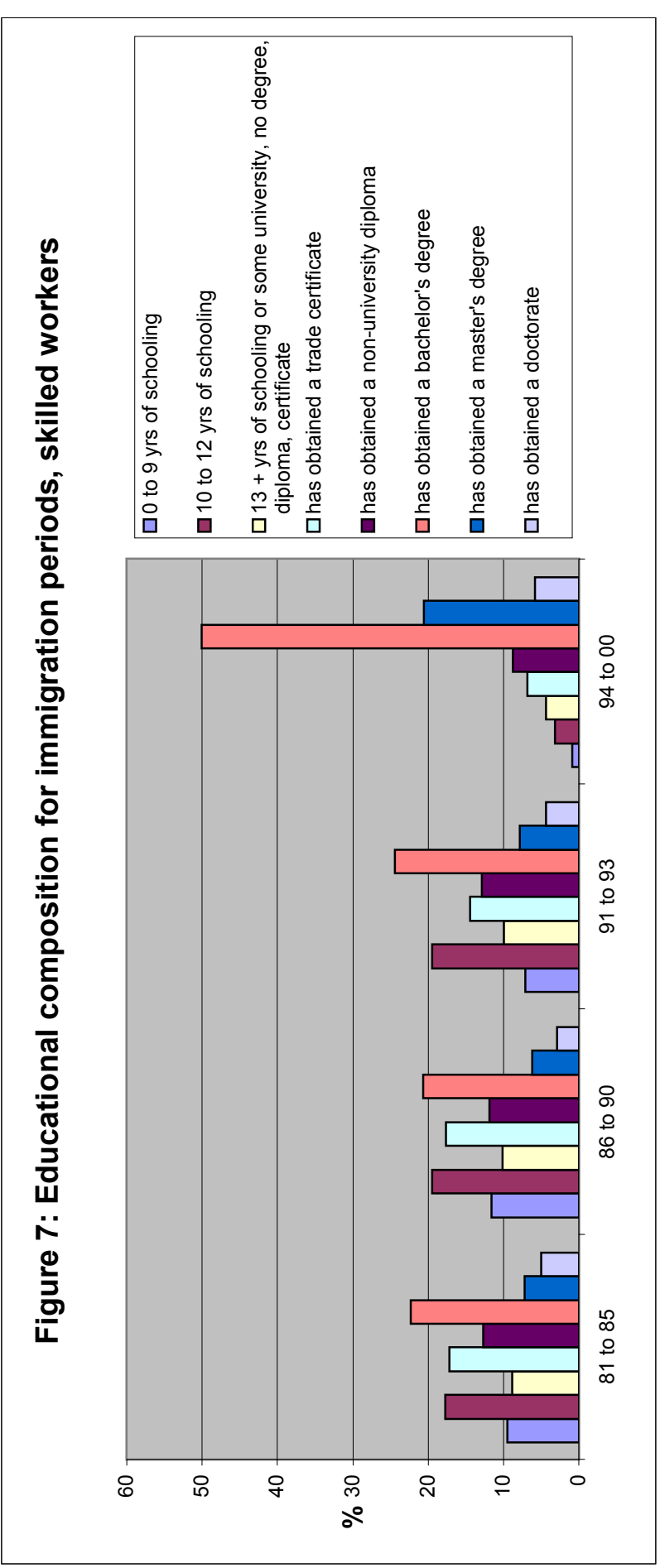


Heather Dryburgh

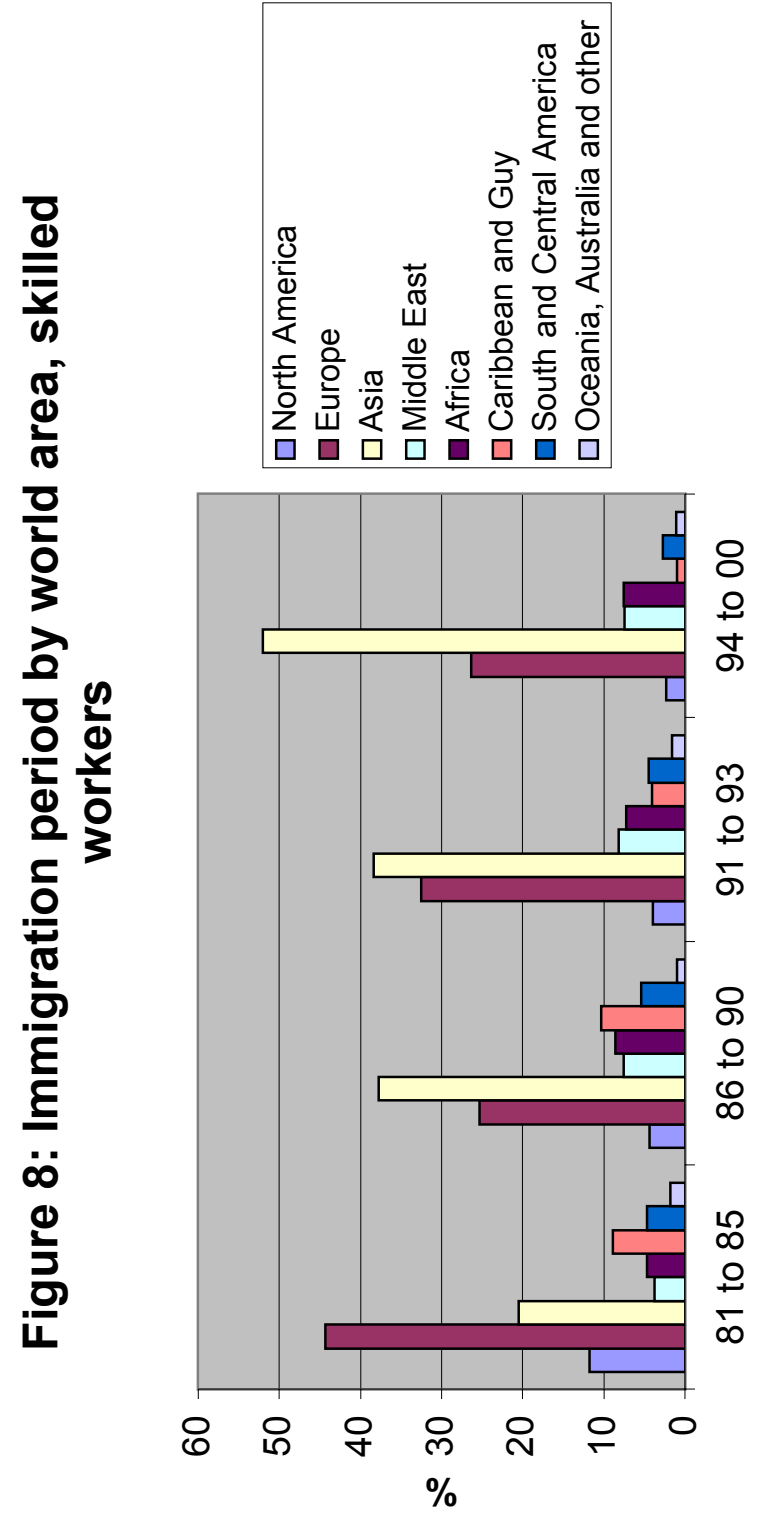


Social Structures and the Occupational Composition of Skilled Worker Immigrants to Canada

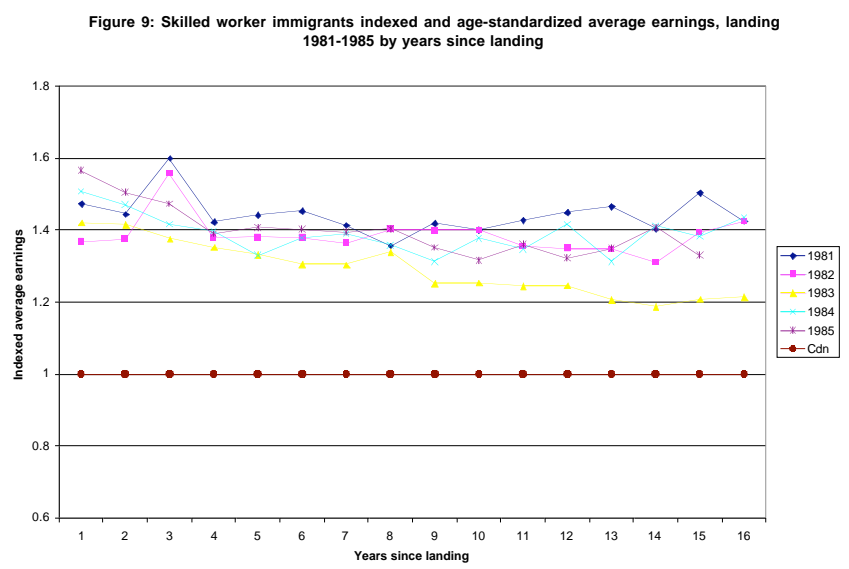

Figure 10: Skilled worker immigrants indexed and age-standardized average earnings, landing 1986-1990 by years since landing

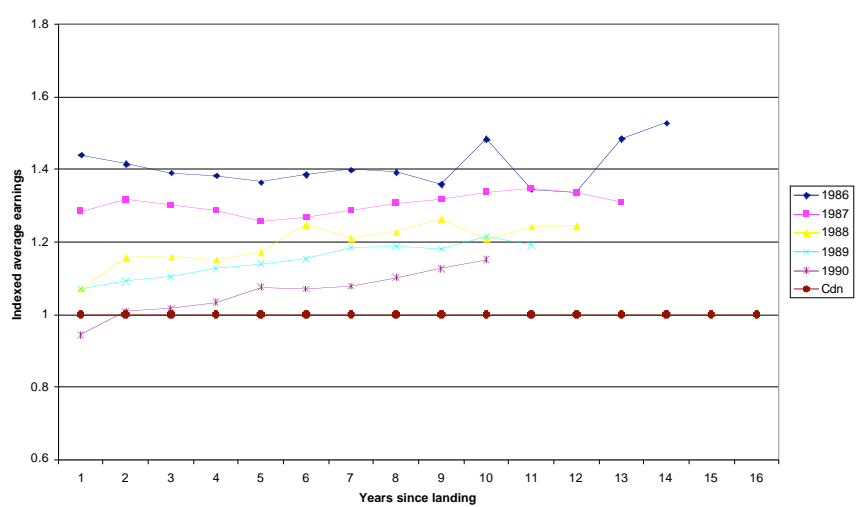

Source Figure 9 and 10: IMDB, Statistics Canada 
Heather Dryburgh

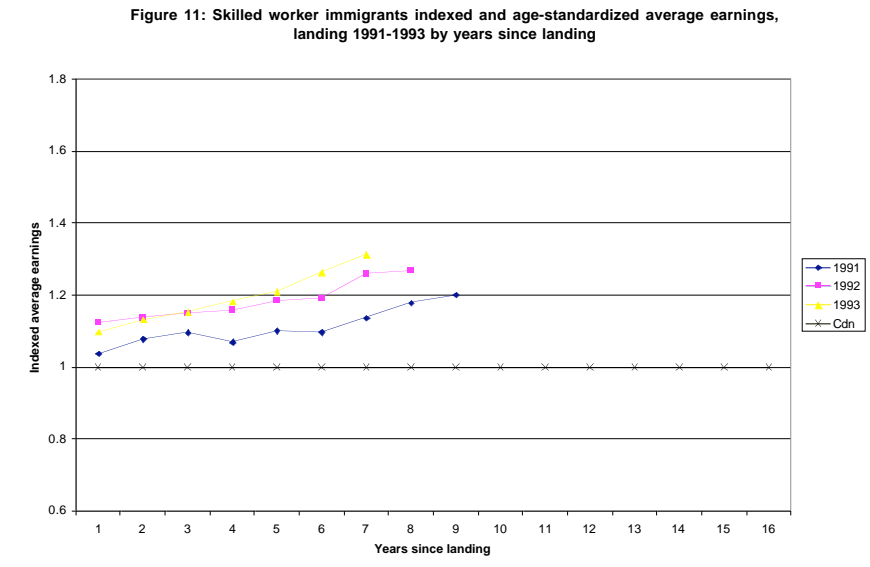

Figure 12: Skilled worker immigrants indexed and age-standardized average earnings, landing 1994-1999 by years since landing

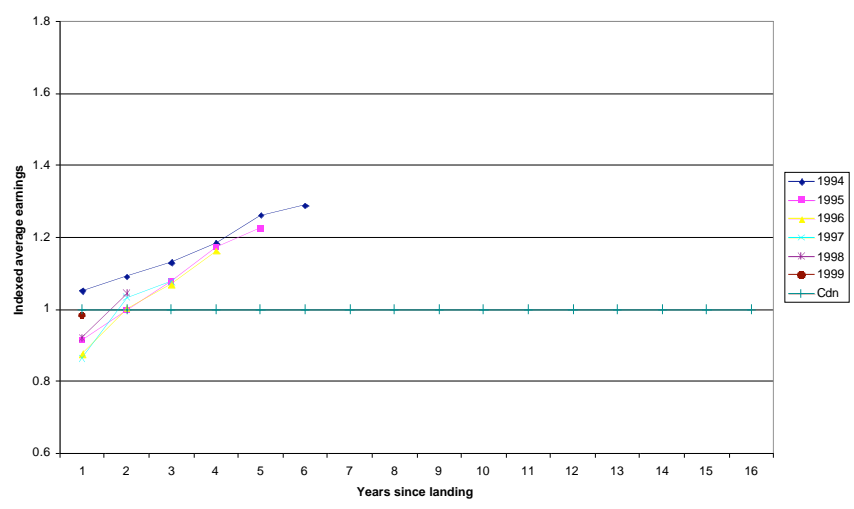

Source Figures 11 and 12: IMDB, Statistics Canada 
earlier cohort group, relative to all Canadians (Figure 10). Another one in four of the skilled workers intended to work in management occupations or in natural and applied sciences occupations. Although sales and service occupations on average are low-paying, trades workers earn mid-range incomes, while managers and those in natural and applied sciences earn on average among the highest incomes of the broad occupational groups (Labour Force Survey, 2004). Thus the lower income trends may reflect a lag between landing and finding work in the higher paying occupations as well as increasing competition from an expanding pool of well-educated Canadian born participants in the labour market, especially women.

The distribution of the skilled worker immigrants of this period is older than the previous period, somewhat less educated, and more likely to come from Asia or the Caribbean than those who landed in 1981-85. A large share of skilled worker immigrants also came from Europe in this period, but compared with the previous group of cohorts, the percentage from Europe had decreased substantially, from close to one half to about one quarter. Others have noted the employment issues relating to the shifting mix of country of origin, such as the lower returns to foreign education and experience from non-English source countries, and issues of discrimination against visible minorities (Pendakur \& Pendakur 2000; Li 2000; Reitz 2000).

\section{1 to 1993}

The third period comprises immigrants landing from 1991 to 1993 at a time when Canadian immigration policy was being modified to give greater priority to economic immigrants. The economy was in recession from 1990 to 1992 with overall unemployment still high until 1993. The unemployment rates had peaked in trades and manufacturing occupations by 1991 and were in a steep decline in the subsequent few years, whereas unemployment rates continued to rise for occupations such as health, management, and the social science, education, government and religion occupational group. So, demand was still high but was decreasing in the occupational groups requiring higher education and skills and had begun to increase in those occupations requiring less education and skills through this period. Women's labour force participation continued to increase, but the proportion of women in the labour force had started to stabilize at about 45 percent. By contrast, the proportion and number of older workers aged 45 to 64 in the labour force was beginning a steep increase that would continue to 2003 , the most recent year for which data are available. 
Heather Dryburgh

Immigrants landing in the 1991 to 1993 period were thus landing at a time when there was low overall labour demand. Meanwhile it was becoming more and more difficult for immigrants with less than a university education to reach the selection point requirements. In addition, older workers were increasingly dominating the labour force and potentially taking those high paying jobs that require experience. The skilled worker immigrants of this period started off somewhat worse than all but the 1990 cohort, however they surpassed the total Canadian average, and the relative earnings of these cohorts increased fairly steadily after the second year.

Over one third of the approximately 55,700 skilled worker immigrants who gained permanent residence in Canada from 1991 to 1993 intended to work in sales and service occupations where the unemployment rate was fairly high and increasing at this time. An additional $21 \%$ intended to work in natural and applied sciences occupations where the demand was somewhat higher. A smaller percentage of skilled worker immigrants landed with the intention of working in trades occupations compared with previous cohorts.

These immigrant cohorts are older than the two previous groups of cohorts, with a higher percentage of skilled workers in the 30 to 44 age groups. Although about one fifth of these immigrants had only 10 to 12 years of education, the percentage with university degrees increased, surpassing that of the two earlier cohort groups. Asia and Europe continued to be the primary sources of skilled worker immigrants at this time, accounting for about two-thirds of the 1991 to 93 cohorts.

\section{4 to 2000}

The final period of 1994 to 2000 was a period of economic boom with an immigration policy targeting skilled workers. The gender gap was pretty stable through this period with only a very slight closing of the gap. The number and proportion of older workers in the labour force continued to increase steeply, and the demand grew in most occupational groups except in occupations associated with primary industry. Participation in the labour force grew strongly in the sales and service occupations, manufacturing, and natural and applied sciences, whereas labour force participation in trades occupations remained steady. So, while immigrant women would not be facing increasing competition with Canadian women entrants to the labour market, immigrants faced increased competition with older workers.

In the 1994 to 2000 period, approximately 200,900 skilled worker immigrants became permanent residents in Canada. The occupational composition of this 
group of cohorts was dominated by those intending to work in natural and applied sciences occupations where the demand continued to grow throughout these years. Meanwhile, for the first time since the 1980s the share of skilled worker immigrants intending to work in sales and service occupations decreased to below 10 percent. Otherwise, skilled workers of this period were fairly evenly distributed across the remaining occupational groups, with somewhat higher proportions intending to work in professional occupations in business and finance, and financial, secretarial and administrative occupations.

The age distribution of this cohort group follows the same trend as mentioned earlier - the proportions of skilled workers in the 30 to 44 age groups continued to increase, while fewer skilled workers in the younger and older age groups landed in this period. The educational profile of this period is quite different from earlier cohorts, with more than three quarters of skilled worker immigrants landing with a university education. By comparison, $34 \%$ of the 1981 to 85 cohorts, $30 \%$ of the 1986 to 90 cohorts, and 36\% of the 1991 to 93 cohorts had a university education. In sum, this group of immigrant cohorts were better educated, more experienced, had better language ability on average, and they landed in Canada at a time of economic growth. In addition, they intended to work in high demand occupations, yet one year after landing, this rather elite group earned below the average for all Canadians, except for the 1994 cohort.

In a marked increase from previous cohorts, over half of the 1994 to 2000 skilled worker immigrants came from Asia, and an additional quarter of these immigrants came from Europe. The share of skilled workers from North America, the Caribbean and Guyana, and South and Central America decreased in this period. We know from previous research that source country mix has an effect on the integration of immigrants (Pendakur \& Pendakur 2000; Li 2000; Reitz 2000), and in addition, the increasingly well-educated Canadian born were competing for the higher paying "knowledge-based" jobs (Reitz 2000). Nevertheless, the data show a sharper increase in earnings after the first year compared with other cohort groups, so while somewhat delayed, the earnings of these highly qualified immigrants quickly increased to the levels one would expect given differences between their qualifications and the average qualifications for all Canadians. The technology boom of the 1990s benefited Canadians as well as providing opportunities for qualified immigrants.

\section{IT Workers}

Clearly the technology boom that dominated the 1990s played a role in accounting for the substantial changes in the occupational composition of immigrant skilled workers in the 1990s. Over that period there was strong 
Heather Dryburgh

international competition for information technology (IT) workers. Concerns about a growing shortage of skilled labour in its member countries prompted the Organization for Economic Co-operation and Development (OECD 2000a, $2000 \mathrm{~b}$ ) to propose measures of the 'international mobility of human resources in science and technology.' Many OECD member countries had active recruitment programs for IT workers through this period, including the Canadian government. The Canadian Innovation Strategy (Industry Canada, 2001) identified the need to strengthen the IT labour force in Canada in part through attracting immigrants with qualifications and intentions to work in IT occupations. The closer analysis of the case of IT workers that follows is thus a good example of the complex relationship between social and economic structures, the occupational composition of immigrants, and their economic integration.

The first part of the results and discussion focuses on all immigrants who land with the intention of working in IT (supply), followed by a closer look at only those who report earnings (utilization of supply). In the 1990s and 2000 almost 92,000 immigrants became permanent residents in Canada with the intention of working in IT occupations (Table 1). Almost 73,500, or 80 percent of these immigrants intended to work as electrical and electronics engineers, computer systems analysts or computer programmers. Computer engineers, electrical and electronic engineering technologists and technicians, electronic service technicians, and graphic designers and illustrators comprised the remaining 20 percent. Census data for 2001 showed that one in three people working in the computer specialties were immigrants, and nearly half of these came in the 1990s (Habdu 2003).

In 1990 immigrant IT occupations comprised less than three percent of all intended occupations for men, but by 2000 they comprised 13 percent. For immigrant women, the share of IT workers in 1990 was less than one percent and increased through that decade to three percent by 2000. In comparison, the Canadian 2001 Census data indicated that three percent of all employed Canadians worked in computer specialties (Habdu 2003), much lower than was the case for immigrant men from the $1990 \mathrm{~s}$, but comparable to immigrant women.

Most immigrant IT workers gained permanent residency between the ages of 25 and 44 years (90 percent), and the majority had earned their educational qualifications in their sending country. A noteworthy 79 percent of men and 80 percent of women immigrant IT workers landed in Canada with a bachelor's degree or higher. The high education levels of immigrant IT workers greatly surpassed that of all Canadians, where 44 percent of all IT workers had at least a bachelors degree according to the 2001 Census (Habdu 2003). 
Social Structures and the Occupational Composition

of Skilled Worker Immigrants to Canada

In summary, the growing supply of immigrant IT workers to Canada in the 1990s and 2000 was characterized by high educational and language resources compared to other immigrants (non-IT workers) and to Canadian-born IT workers. How well Canada utilized immigrant IT worker knowledge and skills can be assessed by the number of years it took to first report employment or self-employment earnings. Immigrant IT workers were much more likely to report earnings by the end of the first year after landing than immigrant non-IT workers. About 61 percent of IT workers reported earnings by one year after landing, compared with only 36 percent of all other immigrants intending to work. Of those who reported earnings, 81 percent subsequently did so consistently up to 2000, compared with 66 percent of other immigrant workers with earnings. Thus, while immigrant IT workers were to some extent underutilized, they far surpassed other immigrants intending to work, in speed of integration, overall success in gaining employment, and in stability of employment.

Of the IT occupations, immigrants were least likely to intend work as information systems and data processing managers in the 1990s and 2000, and those who did were less successful at gaining quick employment, had less stability and were less likely to report income from any source than the other IT occupations. This finding is in line with previous research that shows immigrants are doing well in professional occupations, but are less likely than non-immigrants to move into management positions (Boyd \& Thomas 2001).

Language barriers, the state of the economy and the extent and recognition of resources immigrants bring with them, all affect the chances of gaining employment for recent immigrants. The following logistic regression analysis controls for important factors affecting employment to assess the impact of gender and occupation on the labour market experience of immigrants.

\section{Regression Analysis and Discussion}

The odds ratios presented in Table 3 are interpreted in relation to the reference category; odds ratios above one indicate higher odds of earnings or stability than the reference group ${ }^{7}$, and odds ratios below one indicate lower odds than the reference group. The stronger the relation, the farther the odds ratio will be from one. The first model shows significant effects of gender and occupation on the odds of reporting earnings by the first year after landing, controlling for other characteristics. The bivariate analyses suggested that immigrant IT workers were integrating more quickly than other immigrants intending to work. That finding remained true only for the non-engineering IT occupations once 
Heather Dryburgh

Table 3

Logistic Regression of Sex and Occupation on Probability of reporting Earnings by First Year after Landing, with Controls

\begin{tabular}{|c|c|c|c|c|}
\hline \multirow[b]{2}{*}{ Parameter } & \multicolumn{2}{|c|}{$\begin{array}{c}\text { Odds of earnings 1st yr } \\
\text { after landing }\end{array}$} & \multicolumn{2}{|c|}{ Odds of stable earnings } \\
\hline & Odds ratios & $\begin{array}{c}\text { Pr } \\
>\text { ChiSq } \\
\end{array}$ & Odds ratios & $\begin{array}{c}\text { Pr } \\
>\text { ChiSq } \\
\end{array}$ \\
\hline Landed 1996 to 1998 & 1.839 & & 2.82 & \\
\hline Landed 1990 to 1995 (ref) & 1.00 & & 1.00 & \\
\hline Female & 0.6 & & 0.83 & \\
\hline Male (ref) & 1 & & 1 & \\
\hline English & 1.3 & & 1.13 & \\
\hline French & 0.9 & & 0.83 & \\
\hline English and French & 1.1 & & 0.85 & \\
\hline Neither (ref) & 1 & & 1 & \\
\hline Other & 0.2 & & 2.51 & $* *$ \\
\hline Africa, M East* & 0.6 & & 1.13 & \\
\hline Asia, Australia \& Pacific & 0.8 & & 1.7 & \\
\hline Latin America, Greenland* & 0.7 & & 1.54 & \\
\hline Europe except UK & 1.0 & & 1.7 & \\
\hline United Kingdom & 1.2 & & 1.55 & \\
\hline US (ref) & 1 & & 1 & \\
\hline 0-9 yrs schooling & 0.3 & & 1.08 & \\
\hline 10-12 yrs schooling & 0.8 & & 0.87 & \\
\hline $13+$ yrs, no degree & 1.0 & & 0.84 & \\
\hline Trade certificate & 1.1 & & 0.95 & \\
\hline Non-univ diploma & 1.0 & & 0.95 & \\
\hline Masters & 1.0 & & 0.81 & \\
\hline Doctorate & 1.0 & & 0.93 & ** \\
\hline Bachelors (ref) & 1 & & 1 & \\
\hline Family & 0.9 & & 0.98 & ns \\
\hline Business & 0.3 & & 0.9 & \\
\hline Other economic & 0.4 & & 1.11 & \\
\hline Refugee & 0.5 & & 0.74 & \\
\hline Other & 0.9 & & 1.06 & \\
\hline Skilled worker (ref) & 1 & & 1 & \\
\hline IT occs, no engineers & 1.2 & & 1.26 & \\
\hline IT engineering occs & 0.9 & & 1.25 & \\
\hline Non-IT occs (ref) & 1 & & 1 & \\
\hline Age at landing & 1.0 & & 0.98 & \\
\hline Intercept estimate & 0.2836 & & 0.4655 & \\
\hline Chi-square & 174,684 & & 47,997 & \\
\hline Degrees of freedom & 26 & & 26 & \\
\hline $\operatorname{Pr}>C h i S q$ & 0.0001 & & 0.0001 & \\
\hline
\end{tabular}

* Includes some islands of Atlantic \& Indian oceans

Unless otherwise noted, all odds ratios are significant at $\mathrm{p}<.001$

**Significant at .05 level of probability

ns Not significant 
Social Structures and the Occupational Composition

of Skilled Worker Immigrants to Canada

Table 4

Occupational Composition over Structural Proxy Periods ${ }^{1}$

\begin{tabular}{|c|c|c|c|c|c|}
\hline Proxy Period & $\begin{array}{c}\text { Management } \\
\text { occupations }\end{array}$ & $\begin{array}{c}\text { Professional } \\
\text { occupations in } \\
\text { business and finance }\end{array}$ & $\begin{array}{c}\text { Financial, } \\
\text { secretarial and } \\
\text { administrative } \\
\text { occupations }\end{array}$ & $\begin{array}{c}\text { Clerical } \\
\text { occupations, } \\
\text { including } \\
\text { supervisors }\end{array}$ & $\begin{array}{l}\text { Natural and applied } \\
\text { sciences and related } \\
\text { occupations }\end{array}$ \\
\hline $1981-1985$ & 9.4 & 3.7 & 2.9 & 1.7 & 22.9 \\
\hline $1986-1990$ & 11.5 & 4.1 & 8.3 & 2.3 & 12.8 \\
\hline 1991-1993 & 6.6 & 2.0 & 4.3 & 1.7 & 21.4 \\
\hline $1994-2000$ & 2.2 & 7.2 & 7.2 & 1.0 & 56.0 \\
\hline Proxy Period & $\begin{array}{l}\text { Professional } \\
\text { occupations in } \\
\text { health, nurse } \\
\text { supervisors and } \\
\text { registered nurses }\end{array}$ & $\begin{array}{c}\text { Technical, assisting } \\
\text { and related } \\
\text { occupations in } \\
\text { health }\end{array}$ & $\begin{array}{l}\text { Occupations in } \\
\text { social science, } \\
\text { education, } \\
\text { government service } \\
\text { and religion }\end{array}$ & $\begin{array}{l}\text { Occupations in art, } \\
\text { culture, recreation } \\
\text { and sport }\end{array}$ & $\begin{array}{l}\text { Sales and service } \\
\text { occupations }\end{array}$ \\
\hline $1981-1985$ & 5.4 & 1.0 & 8.3 & 2.7 & 23.0 \\
\hline $1986-1990$ & 3.8 & 1.8 & 5.1 & 2.6 & 23.5 \\
\hline 1991-1993 & 4.9 & 1.5 & 6.9 & 2.7 & 33.7 \\
\hline $1994-2000$ & 2.1 & 1.7 & 5.5 & 3.9 & 7.6 \\
\hline Proxy Period & $\begin{array}{l}\text { Trades, transport } \\
\text { and equipment } \\
\text { operators and } \\
\text { related occupations }\end{array}$ & $\begin{array}{l}\text { Occupations unique } \\
\text { to primary industry }\end{array}$ & $\begin{array}{l}\text { Occupations unique } \\
\text { to processing, } \\
\text { manufacturing and } \\
\text { utilities }\end{array}$ & & \\
\hline $1981-1985$ & 12.3 & 2.2 & 4.8 & & \\
\hline $1986-1990$ & 15.7 & 0.7 & 7.8 & & \\
\hline 1991-1993 & 8.9 & 0.6 & 4.9 & & \\
\hline $1994-2000$ & 5.1 & 0.2 & 0.5 & & \\
\hline
\end{tabular}

'Source: LIDS, Citizenship and Immigration Canada, 2000 
Heather Dryburgh

other factors were controlled for in the multivariate analysis. Immigrants intending work in engineering IT occupations did not have a higher probability of early earnings than those in non-IT occupations, despite the need for workers with these qualifications. The lag for engineers has been found in other research and explained by the accreditation process of the engineering profession (Boyd \& Thomas 2001).

Compared with non-IT occupations, immigrants intending to work in IT had about 1.3 times higher odds of reporting stable earnings once they first reported earnings. Looking at Table 3, the computer professionals - engineers, systems analysts and programmers - who arrived in the 1990s were the most likely occupational groups to report stable earnings. Despite the lag to engineers first reporting earnings as noted above, once employed, these immigrant professionals appear to be keeping their employment.

Gender differences in early earnings found in bivariate analysis remained after adjusting for human capital measures, immigrant category, country of last permanent residence and age: women had lower odds of reporting early earnings than men, holding these factors constant. Women's odds of early earnings were .7 times those of men with similar characteristics, and their odds of stable earnings were .8 times that of comparable men. It appears that immigrant women continued to feel the impact of gender on their labour force experiences despite the demand for IT workers through the 1990s.

\section{Conclusions}

Relative to Canadians, when all immigrants are grouped together, their economic integration is slow and does not reach parity with Canadians before 16 years. The differences found when comparing all immigrants with skilled worker immigrants suggests it is problematic to try to explain integration findings without considering both the class of immigrant and the context at the time of immigration. Other recent analysis of immigrant labour market performance suggests it is 'bipolar' in character: the majority of immigrants have followed a worsening trend, but the much smaller subgroup of immigrant professionals and highly skilled workers have not experienced a similar downward tendency (Castles \& Davidson 2000). The present study suggests, however, that the distinction may not be as clear as that. Among skilled worker immigrants, the integration patterns change over time, so whereas the earlier cohorts did well and yet did not improve much over time, later cohorts started off in a worse position, but early indications show a fairly steep slope to better relative average earnings. In relation to the example of IT workers, the 
Information and Communication Technology (ICT) sector performed well in the 1990s during periods of decline in other sectors (Vaillencourt 2001). IT workers recruited to Canada were largely in the higher skilled group and were seeking work predominantly in the ICT sector. The indicators of integration in this study attest to their relatively successful entry into IT work through the 1990s.

The occupational composition of skilled worker immigrants over the 1980s and 1990s changed from a sales and service, sciences and trades composition, to one very much dominated by natural and applied science occupations. Therefore, the age, gender and education characteristics of workers competing for these jobs were different across the cohorts. In addition, the ease of entering into work varies by occupations, and some highly skilled occupations have entry conditions of certification or recognition by a professional body. The differences in occupational composition, and the potential impact on immigrant integration of these differences underline the need to control for occupational composition, and to account for context in the study of immigrant integration.

\section{End Notes:}

1. Immigrants may not actually work in that occupation after landing, however, the intended occupation is the best source of information to describe the composition, on landing, of skilled immigrants that Canada has been attracting.

2. Landing year is the year the immigrant became a permanent resident of Canada. The term 'landing' is used interchangeably with 'permanent residency' in this paper. Both terms refer to the time an immigrant enters Canada with documentation and is given permanent resident status

3. The Occupational and Area Demand report assessed combined population and occupation needs by geographic regions of Canada.

4. The points for occupational demand were based on the Canadian Occupational Projection System (COPS), which was based on current and projected employment, and unemployment rates. In addition, in 1986 some jobs were excluded since they would not be open to new immigrants, such as those requiring Canadian citizenship.

5. Baby boomers include people born from 1946 to 1962 .

6. This excludes those that landed as assisted relatives. 
Heather Dryburgh

7. All odds ratios are relative to a reference category for each categorical predictor variable. For example, if the reference category for country of last permanent residence is the US, then odds ratios over 1.0 indicate a higher probability of earnings by the first year after landing than is the case for immigrants from the US.

\section{References:}

Aydemir, A. (2003). Effects of Business Cycles on the Labour Market Participation and Employment Rate Assimilation of Immigrants, forthcoming in Canadian Immigration Policy for the 21st Century, edited by Beach, C. and A. Green. John Deutsch Institute, Kingston: Queen's University Press.

Aydemir, A. (2002). Effects of Selection Criteria and Economic Opportunities on Immigrant Characteristics. Statistics Canada Catalogue no. 11F0019MIE - No. 182.

Bowlby, G. and S. Langlois. (2002). High-tech boom and bust. Perspectives on Labour and Income. Statistics Canada Catalogue no. 75-001-XIE.

Boyd, M. and M. Vickers. (Autumn, 2000). 100 years of immigration in Canada. Canadian Social Trends. Statistics Canada Catalogue No. 11-008.

Chui, T. and D. Zietsma. (Autumn, 2003). Earnings of immigrants in the 1990s. Canadian Social Trends. Statistics Canada Catalogue No. 11-008.

Green, D.A. and C. Worswick. (2002). Earnings of Immigrant Men in Canada: The Roles of Labour Market Entry Effects and Returns to Foreign Experience. Paper prepared for Strategic Policy, Planning and Research Branch, Citizenship and Immigration Canada.

Kim. A.H. (2003). Determinants of international migration flows. Paper presented at the 2003 Canadian Population Society meetings, Halifax, June 2003.

MacKenzie, A. and H. Dryburgh (2003). The Retirement Wave. Perspectives on Labour and Income. Statistics Canada Catalogue no. 75-001-XIE. 
Social Structure and Occupational Composition of Skilled Worker Immigrants to Canada

McWhinney, M. (1998). Immigration Policy Regimes: Legislative, regulatory and program changes affecting IMDB Data Analysis, 1980-1995. Strategic Research \& Review Branch, Citizenship \& Immigration Canada.

Petrov, A. N. (2003). Contemporary out-migration from the Canadian and Russian North: Understanding spatial differences and similarities. Paper presented at the 2003 Canadian Population Society meetings, Halifax, June 2003.

Reitz, J.G. (2000). Immigrant Success in the Knowledge Economy: Institutional Change and the Immigrant Experience in Canada, 1970-1995.

Sassen, S. (1988). The mobility of labor and capital: A study in international investment and labor flow. Cambridge: Cambridge University Press.

United Nations. (2002). International Migration Report 2002. UN Population Division: New York.

Vaillancourt, C. (2003) 'A profile of employment in computer and telecommunications industries', Statistics Canada, Cat. No. 56F0004MIE, No. 9. 
Heather Dryburgh

Appendix 1: Selection criteria for immigration to Canada

Factor

Education

Specific Vocational Preparation

Experience

Occupation

Arranged employment

Location

Age

Knowledge of French or English

Personal Suitability

Levels Control

Relative

Source: Citizenship \& Immigration Canada
Max. Units of Assessment

$1978 \quad 1986$

12

12

$15 \quad 15$

$8 \quad 8$

$15 \quad 10$

$10 \quad 10$

$5 \quad 0$

$10 \quad 10$

$10 \quad 15$

$10 \quad 10$

NA $\quad 10$

50

$100 \quad 100$

\begin{tabular}{ll}
\hline & Appendix 2: List of IT occupations \\
\hline SOC91 & Occupation Name \\
\hline & \\
\hline A122 & Information systems and data processing managers \\
\hline C033 & Electrical and electronics engineers \\
\hline C047 & Computer engineers \\
\hline C062 & Computer systems analysts \\
\hline C063 & Computer programmers \\
\hline C141 & Electrical and electronics engineering technologists and technicians \\
\hline C142 & Electronic Service technicians \\
\hline F141 & Graphic designers and illustrators \\
\hline
\end{tabular}

